\title{
Community care plans and the Mental Illness Specific Grant
}

\section{Recent government policy and legislation}

\author{
Jeff Doodson and Sara Davies
}

\begin{abstract}
Mental Illness specilic Grant was made avallable to local authortiles for the care of people with severe mental illness, as part of care in the community. Although only a small sum of money it has had the effect of oiving the newty created community care planning system a boost stat. It has encibled professionats from all agencles to see tanglble beneitts from collaborative working. MISG is time limited but has already shown that health and social services can work togother to make a reality of community care.
\end{abstract}

In September 1990 a government press release announced that a specific grant was to be made avallable to local authorities for the social care of people with severe mental illness (Department of Health, 1990). This Mental Illness Specific Grant (MISG), provided funding as part of care in the community, as a means of continuing the expansion of community-based services and contraction of the large psychiatric hospitals. Under the NHS and Community Care Act (House of Commons, 1990), local authorities are responsible for providing social care to a range of people with special needs including those with severe mental illness. Because of finite resources it was recognised that the money to provide this care would need to be safeguarded in order to prevent it from being used for other purposes. The MISG was a way that was seen for this to happen.

\section{The facts}

The MISG was introduced by the Department of Health in 1991/92 as a three year revenue grant, later extended for a year and recently given a further three year extension. The grant is payable to local authorities who must get the local and regional health authority's agreement to their plans for its use. The individual local authority allocations are decided by calculations based on the population structure.

MISG is not an increase in money; it is instead a directive from central government on how part of the local authorities' budget should be spent. The money that previously would have gone directly to local authorities is now only avallable through the Department of Health in the form of MISG. This money, payable from the Department of Health, represents 70\% of the total needed and a further $30 \%$ is required to be paid as new money' by a local authority or another source to enable the grant to be released.

For the year 1993/94 Southwark, an inner London borough, had an allocation of MISG of $£ 256,000$ and its budget for all mental health provision was $£ 2,442,000$. In the same period the South East London Health Authority, which covers three boroughs including Southwark, planned to spend $£ 19,600,000$.

The scope of the MISG as defined by the Department of Health (1990) is to provide social care for two specific client groups.

(a) Any kind of social care that is agreed by the social services departments and the appropriate health authority(ies) as necessary to contribute to the health and social care needs of people whose mental illness (including dementia) is so severe that they come within the remit of the care programme approach.

(b) Social care aimed at bringing in touch with the specialist psychiatric services people in the community not currently in touch with these services but whose needs are so severe that it is clear that they would benefit from these services, for example those among the homeless population whose seriously impaired social functioning is a consequence of mental illness.

\section{Effects on organisations}

One of the main effects of the MISG, in providing specific monies for mental health, has been to bring different agencies together to see how best they can spend this money and plan how they can meet the needs of the severely mentally ill in their area. 
In the early days in Southwark there was a general air of mutual mistrust, with health professionals believing that the social services department would divert any new money to child care; and social services certain that health professionals would use any funds for acute services. Fortunately these fears were soon recognised to have been misplaced as the negotiations that were needed to use the MISG laid the foundation for effective planning and joint ventures between different agencies.

In its first year, because there was only a short time to bid for the money, there was little scope for strategic planning. Difficult areas to negotiate were decisions on the distinction between health and social care; for instance who should be providing day care/centre places. Later these discussions focused more positively on the creation of a 'seamless service'. This was enhanced by the joint writing of philosophy in the form of mission statements and agreeing common terminology.

For their part social services departments, under continuing financial squeeze, regarded MISG as a mixed blessing, especially in the requirement to provide a $30 \%$ contribution. However, through joint planning in Southwark, the MISG has been used successfully in the past two years to fund a number of ventures including a mental health resource centre, a respite care project for the elderly mentally infirm, community support workers based with a care management team, a day centre for the elderly mentally ill, and smaller grants to support the majority of voluntary health and social agencies in the borough.

The MISG has enabled the establishment of effective working mechanisms for joint planning of resource allocation. This allows rapid dissemination of knowledge about extra available monies and decisions can be made rapidly about its use.

\section{Implications for individual psychiatric practice}

The government guidelines stressed the importance of understanding that planning is not an end in itself - but should be used to promote better outcomes for clients. The old planning system was based more on avallable services than on patients' needs. In order to secure funding, the MISG requires individual psychiatrists to develop comprehensive assessments of their patients' needs and evaluation of the services that they can provide to meet these needs.

In a national survey of the use of the MISG, the National Schizophrenia Fellowship (1991), reported that a large percentage of the money from the MISG had been spent on the provision of mental health resource centres that has enabled psychiatrists to work more effectively in the community. The MISG has also provided money for new psychiatric initiatives, for example crisis and respite houses in Southwark, which were unlikely to have obtained money through the usual channels. It is essential to know how the MISG has been used nationally since 1991 .

In Southwark, a planning forum has established itself as the authority for service planning in the area. Health purchaser and provider agencies are all represented and individual psychiatrists can become involved either through their employing organisation or as individuals they have the right to comment on or challenge the community care plan and hence influence the local authority spending on mental health services.

\section{Implications for users of mental health services}

The community care legislation puts a heavy emphasis on consulting with and involving users of services in the planning process. In Southwark a users' forum has been established. This has been effective in users having a voice in Southwark and being involved in the planning of services for the mentally ill and the allocation of the MISG. It is through this process, particularly at the stage of influencing resource allocation. that users will have a direct way of affecting services.

\section{Implications for working arrangements with purchasers and providers}

The purchaser/provider split was noted in the first years of joint planning but until recently had not featured as an issue for the working of the multi-agency planning group.

At present there is good co-operation between different agency providers because the emphasis of the planning group on allocation resources is equity. However already overall service priorities have been produced with which all the constituent organisations on the planning group agree. Future spending decisions will be based on a strategic approach to service provision and will inevitably produce winners and losers.

More recently the emphasis in the community care plans has begun to shift to the production of a purchasing strategy. For example, in Southwark community care and MISG plans are now becoming purchasing documents.

\section{Conclusions}

The MISG is only a small amount of money in comparison to that spent on the severely 
mentally ill as a whole. Having had two extensions it will now last for a period of seven years and will end in 1998. However, owing to uncertainty over the life of the grant, it has not helped in the more longterm strategic planning and funding of mental health services. However in Southwark it has had a major effect in facilitating the establishment of joint service planning between health and social services, and with other statutory and voluntary agencies and users of mental health services. From this, other forms of joint working have been much easier to achieve. It seems that the MISG has been the main practical stimulus for this collaborative approach in a sea of more general guidelines in the recent government legislation. We need to known more about the effect and use of the MISG nationally.

If health and social services departments can use the MISG to begin the difficult process of jointly planning services for the severely mentally ill, then there is a chance that community care can be a reality.

\section{References}

DePaRtMent OF Health (1990) Specific Grant for the Development of Social Care Services for People with a Mental Illness. HC(90)24LAC(90)10. London: HMSO.

House of COMmons (1990) National Health Service and Community Care Act. London: HMSO.

National Schizophrenia FellowShIP (1991) The Mental Illness Specific Grant: the early days. London: NSF.

*Jeff Doodson, Planning Officer, Southwark Soctal Services, Mabel Goldwin House, 49 Grange Walk, London SE1 3DY; and Sara Davies, Clinical Research Worker and Honorary Senior Registrar, PRiSM (Psychiatric Research in Service Measurement), Institute of Psychiatry, De Crespigny Park, Denmark Hill, London SE5 8AF

*Correspondence

\section{COLLEGE SEMINARS SERIES \\ Seminars in Psychology and the Social Sciences}

\section{Edited by Digby Tantam and Max Birchwood}

Seminars in Psychology and the Social Sciences is a book about basic science for the clinical scientist - psychiatrists (particularly those in training), clinical psychology students, general practitioners, community psychiatric nurses and social workers. Each chapter comprehensively reviews the current state of one aspect of the basic science as it relates to mental health. In some instances the links between clinical practice and the most recent theories considered in this book have yet to be made. However, over the next decade many of these are likely to dominate the research and service agenda, such as ethnicity as a determinant of health care, connectionist models of mental functioning, and the effects of sex and gender on mental health. For the trainee as well as for the clinician looking for new paradigms in the social sciences, the book will prove an essential source.

ISBN 0-902241-62-1 $358 \mathrm{pp}$.

$£ 17.50$

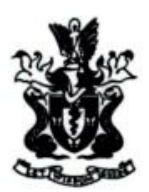

GASKELL 